\title{
Interaction between the body condition score, gait, hindlimb conformation, and claw conformation in dairy cows in Aydin, Turkey
}

\author{
Ibrahim Akin ${ }^{*}$ (D) Husnu Erbay Bardakcioglu ${ }^{2}$ (D) Elvan Hayat ${ }^{3}$ (i) \\ Yalcin Alper Ozturan' ${ }^{1}$ Omer Kurt $^{1}$ (D)
}

${ }^{1}$ Department of Surgery, Faculty of Veterinary Medicine, Aydin Adnan Menderes University, Isikli, ADU Veteriner Fakultesi, 09016, Efeler, Aydin, Turkey. E-mail: ibraak@adu.edu.tr. "Corresponding author.

${ }^{2}$ Department of Animal Science, Faculty of Veterinary Medicine, Aydin Adnan Menderes University, Isikli, ADU Veteriner Fakultesi, Efeler, Aydin, Turkey. ${ }^{3}$ Aydin Faculty of Economics, Aydin Adnan Menderes University, Zafer, Efeler, Aydin, Turkey.

ABSTRACT: Breeding strategies aim to reduce lameness in dairies by using predictor traits to increase the selection of dairy cows. This study enhanced the present knowledge about association between the claw conformations (CC), hindlimb conformation (HiLC), gait, and body condition score (BCS) in dairy cows. A total of 166 lactating Holstein cows were enrolled in the study and scored for BCS, CC, HiLC, and gait. The abnormal HiLC group was statistically significant $(P<0.001)$ to have more abnormal CC. Hock in (Hin) cows showed significance $(P<0.001)$ with $C C$ abnormalities. Cows with abnormal gait have less abnormal claw and limb conformation than normal cows $(P=0.032)$. Lactation number $(P=0.036)$ and abnormal HiLC $(P<0.001)$ were significantly increased risk for CC. The present results might be useful for claw and hindlimb conformations, and breeding strategies of the herd.

Key words: dairy cow, claw conformation, body condition score, limb conformation.

Interação entre o escore corporal, marcha, conformação do membro posterior e conformação do casco em vacas leiteiras em uma fazenda localizada em Aydin, Turquia

RESUMO: Estratégias de melhoramento visam reduzir a claudicação em gado leiteiro usando características preditoras para aumentar a seleção de vacas com alta produtividade. Os objetivos deste estudo foram aumentar o conhecimento atual sobre a associação entre as conformações do casco (CC), conformação dos membros posteriores (HiLC), marcha e escore de condição corporal (BCS) em vacas leiteiras. Um total de 166 vacas Holandesas em lactação foram incluídas no estudo e pontuadas para BCS, CC, HiLC e marcha. O grupo HiLC anormal foi considerado estatisticamente significativo $(P<0,001)$ para ter mais $C C$ anormal. Vacas Hock in (Hin) mostraram significância $(P<0,001)$ com anormalidades CC. Vacas com marcha anormal têm menos conformação anormal de cascos e membros do que vacas normais $(P=0$,032). Número de lactação $(P=0,036)$ e HiLC anormal $(P<0,001)$ aumentaram significativamente o risco de CC. Os presentes resultados podem ser úteis para conformações de cascos e membros posteriores e estratégias de reprodução do rebanho.

Palavras-chave: vaca leiteira, conformação da casco, escore de condição corporal, conformação do membro.

\section{INTRODUCTION}

Lameness is one of the well-known causes of major economic losses and welfare issues and has also a detrimental correlation with milk production and fertility and leads to a higher risk of death or culling in the dairy industry (WARNICK et al., 2001; BICALHO et al., 2008). In this regard, one of the priorities of the dairy industry may be improving the dairy cows, requiring minimal foot trimming with good conformed limbs and claws. Rehabilitation of limb and claw conformation on cow level has been not only a need for big and modern dairies but also conventional farms, which constitute most of the farms in many countries, such as our country. Also, body condition score (BCS) has been considered with claw lesions due to thinning of digital cushion
(BICALHO et al., 2009) and lameness (RANDALL et al., 2015). Providing a good locomotion score (LS) via favorable limb and claw conformation, and BCS may be achieved with genetic improvement. This may be reached through the selections of good score bulls or cows/heifers. Heritability estimation of the limb, claw conformation, and claw disorders described as low (VAN DER LINDE et al., 2010). Due to the missing of producer/farm records of relatives, the mentioned low heritability range may restrain genetic transfer for good limb and claw conformation, which are important to prevent lameness (ZWALD et al., 2004). The minor effect of using bull's information on the genetic improvement of claw measurements and the potential of the positive effect of additional works on claw health was stated (HERINGSTAD et al., 2018). Also, the association between BCS and 
lameness caused by claw lesions was emphasized (GREEN et al., 2014; LIM et al., 2015; RANDALL et al., 2015). Therefore, claw and limb conformation characteristics, and their interaction with BCS still need more observations, and records may serve as data for the improvement of the dairy cows in any size of the farm.

Naturally, the shape of the bovine claw is formed by horn production and wear, and the dimensions of the bovine claw shape have been well described (VERMUNT \& GREENOUGH, 1995). Although, modern dairy feeding techniques promote high-quality horn production, due to less walking, the wear of the claw is generally insufficient. Therefore, one of the aim of the claw trimming routine in dairies is to achieve normal-shaped claws, and it is acceptable that long intervals between claw trimming routines may result in abnormal shaped and wrong balanced claws (SADIQ et al., 2020). In dairy cows, limb conformation can have an impact on claw shapes (van der WAAIJ et al., 2004), and further research is proposed to reveal the relationship between limb and claw conformation (ZWALD et al., 2004; VAN DER LINDE et al., 2010; HERINGSTAD et al., 2018). The objective of this study is to investigate the associations between claw and hindlimb conformation with gait and body condition score in dairy cows, and revealing the relationship between the related traits. Thus, we aimed to contribute to current knowledge of the topics on claw and leg conformation of dairy cattle.

\section{MATERIALS AND METHODS}

The data collection for this study was carried out from a dairy farm located in Aydin, Turkey between June 2016 and August 2016. The selection of dairy farms was carried out with the collaboration of the Cattle Breeders Association of Aydin Province. Out of 4372 registered dairy farms in the Cattle Breeders Association of Aydin Province, a family dairy farm, which was established around 1955 and had not bought in any cattle entry since then, was selected for the study. This means, the farm selected for the study has been used only artificial insemination, but not used outside sources (neighbor/ barn, sale/auction) heifer or cow. Consequently, the mother line of the cows used in this study has not been changed since 1955 .

\section{Animals}

A total of 166 lactating cows (n: 166) of a farm consisted 550 Holstein cattle were used. Cows with any signs of foot disease (sole ulcer, white line separation, digital dermatitis, etc.) were not enrolled in the study, due to the possible effect of foot diseases on gait.

Cows were milked two times daily in a double herringbone milking parlor on the farm. Lactating cows were housed in free-stall barns with concrete stalls covered with mattresses (Promat $^{\mathbb{R}}$, Ontario, Canada) on lying areas. The walking alleys in pens had grooved concrete flooring and were cleaned by automatic scrapers; all walkways to and from the milking barn and holding pen were covered (about 75-85 meters) with rubber mats (DeLaval ${ }^{\circledR}$ Tumba, Sweden). In case of malfunctioned of automatic scrapers the tractor was scraped the concrete flooring once per day. All cows used in the study were between first and fourth parity. Cows were fed a TMR consisting of $45 \%$ concentrate (soybean and cornmeal meal, cottonseed, and canola) and 55\% forage (wheat straw, alfalfa hay, haylage, and corn silage). There was no regular claw trimming. This means that claw trimming is performed when an employee or owner of the farm was noticed overgrown hooves. It was learned that routine claw trimming was performed seven months before the study data was received, by a claw trimmer and or veterinarian of the dairy. According to the farm records, all cows received claw trimming during the dry-off period. Claws were observed and recorded in the milking parlor.

\section{Study design and data collection}

All cows were scored for body condition on a scale of 1 to 5 with 0.25 fractions based on visual inspection defined by EDMONSON et al. (1989) a score of 1 stated as poor condition, and a score of 5 indicated as an obese condition. Collection of data on body condition score (BCS), claw conformation (CC), and hindlimb conformation (HiLC) were completed on feeding time. Data on lactation number (LN) and days in milk (DIM) were extracted from the farm's records. BCS and HiLC were evaluated from the backside of the cow during feeding in their pen.

\section{Evaluation of claw conformation (CC) \\ A total of 664 hind claws (166 left lateral,} 166 left medial, 166 right lateral, and 166 right medial) of 166 cows were observed in the milking parlor for claw conformation. The conformation of each claw (left lateral $=\mathrm{LL}$, left medial $=\mathrm{LM}$, right lateral $=\mathrm{RL}$, right medial $=\mathrm{RM}$ ) was evaluated and recorded in two main groups in regards to the existence of abnormality; as "normal= claw has normal shape and/or size" and "abnormal= claw has abnormal shape and/or size)". The abnormal claw 
conformation group was also divided into subgroups and recorded as, corkscrew claw (CoC), scissor/beak claw (SC), and big/slipper claw (BC), and evaluated (PIJL, 2003; NGUHIU-MWANGI et al., 2012; EGGER-DANNER et al., 2015).

\section{Evaluation of hindlimb conformation (HiLC)}

Hindlimb conformation of each cow (n: 166) was evaluated and recorded into two main groups in regards to the existence of abnormality as "normal= cow has good/normal hindlimb conformation" and "abnormal= cow has an abnormal hindlimb conformation". The abnormal HiLC group was also divided into subgroups, hock in (Hin), one side hock in (OHin), bow-legged (BL), and open legged (OL) and evaluated (RAVEN et al., 1985; PIJL, 2003).

\section{Evaluation of gait}

After milking in the alley, all cows were evaluated for gait assessment and recorded into two groups as "normal= cow has a normal walk" and "abnormal= cow has an abnormal walk" in regards to the SPRECHER et al. (1997). If the cow's gait was normal (score $=1)$, it was recorded into the normal group, and if the cow was presenting any signs of lameness ( score=2, 3, 4 and 5) by SPRECHER et al. (1997) it was recorded into the abnormal group.

\section{Categorization of days in milk and lactation number}

Cows were categorized into three groups for the days in milk (CDIM) as early lactation (1-45 days in milk), peak lactation (46-75 days in milk), and late lactation ( $>75$ days in milk). Also, cows were categorized into two groups for their lactation number $(\mathrm{CLN})$ as young cows (Lactation number $=1$ and 2 ) and old cows (Lactation number $=3$ and 4). Then, cows were categorized as the factors of age (Young: Lactation number $=1-2$, Old: lactation number=3-4), abnormality of HiLC (normal, abnormal), and gait abnormality (normal, abnormal) to measure the effect on claw conformation.

\section{Statistical analyses}

Descriptive statistics of 166 cows were presented with means and standard deviations (SD) for measured variables (BCS and day in milk) and shown as numbers and percentages for categorized as normal and abnormal hindlimb conformation, claw conformation, and gait variables according to the lactation numbers. The distribution of claw conformation for each claw was given as a number and percentages.
A general linear model was performed to determine the effect of claw conformation, hindlimb conformation, categorized days in milk, and categorized lactation number groups on body condition score. Interactions were conducted between claw conformation and categorized days in milk; hindlimb conformation and categorized days in milk; claw conformation, and categorized lactation number; hindlimb conformation and categorized lactation number, in the general linear model. The effect of hindlimb conformation and claw conformation subgroups on body condition score was analyzed with Analysis of Variance (ANOVA).

The relationship between main claw conformation and main hindlimb conformation groups; main claw conformation and abnormal hindlimb conformation subgroups; hock in and claw conformation of each claw; main hindlimb conformation and main claw conformation and gait abnormality was examined by using Pearson's chi-square test. Fisher's exact test was used if the expected count less than 5 for each cell.

The possible factors (lactation number, hindlimb conformation, and gait) were further entered into the logistic regression analysis to determine independent predictors of cow outcome and odds ratio (OR) with univariate analyses for lateral, medial, and general claw conformation. HosmerLemeshow goodness of fit statistic was used to assess model fit. An overall P-value of less than 0.05 was considered to show a statistically significant result. Statistical analyses were performed using the IBMSPSS software version 22.0.

\section{RESULTS}

\section{Descriptive statistics}

A total of 166 cows were enrolled in the study; BCS, DIM, the existence of abnormality of claw conformation, hindlimb conformation, and gait by lactation number (LN) are listed in table 1 . Distributions of claw conformation according to the right-left side and lateral-medial claw (\%) were shown in table 2 .

Interaction between claw conformation, hindlimb conformation, and body condition score

There were no statistically significant differences between the mean BCS of main claw conformation (abnormal and normal) groups $(\mathrm{P}>0.05)$ and main hindlimb conformation (abnormal and normal) groups $(\mathrm{P}>0.05)$. The late lactation group had the highest BCS mean $(3.44 \pm 0.60)$ of the 
Table 1 - Descriptive statistics of the cows according to the lactation numbers.

\begin{tabular}{|c|c|c|c|c|c|}
\hline & & ------1 (68)------- & -----2 (42)----- & ------3 (27)------ & ------4 (29)------ \\
\hline $\mathrm{BCS}($ Mean $\pm \mathrm{SD})$ & & $3.27 \pm 0.64$ & $3.50 \pm 0.52$ & $3.26 \pm 0.75$ & $3.19 \pm 0.60$ \\
\hline Days in Milk (Mean \pm SD) & & $219.97 \pm 101.62$ & $230.45 \pm 97.93$ & $185.00 \pm 77.66$ & $201.48 \pm 102.92$ \\
\hline \multirow{2}{*}{ Hindlimb conformation ( $\mathrm{n}, \%$ ) } & normal & $41(60.3)$ & $21(50.0)$ & $10(37.0)$ & $12(41.4)$ \\
\hline & abnormal & $27(39.7)$ & $21(50.0)$ & $17(63.0)$ & $17(58.6)$ \\
\hline \multirow{2}{*}{ Claw conformation $(\mathrm{n}, \%)$} & normal & $41(60.3)$ & $20(47.6)$ & $8(29.6)$ & $9(31.0)$ \\
\hline & abnormal & $27(39.7)$ & $22(52.4)$ & $19(70.4)$ & $20(69.0)$ \\
\hline \multirow{2}{*}{ Gait (n, \%) } & normal & $5(7.4)$ & $3(7.1)$ & $7(25.9)$ & $13(44.8)$ \\
\hline & abnormal & $63(92.6)$ & $39(92.9)$ & $20(74.1)$ & $16(55.2)$ \\
\hline
\end{tabular}

BCS: Body condition score. SD: Standard deviation.

CDIM groups. This value was significantly higher than the early and peak lactation groups $(\mathrm{P}<0.001)$. It was determined that different levels of lactation (CDIM) did not affect claw conformation $(\mathrm{P}=0.886)$ and hindlimb conformation groups $(\mathrm{P}=0.702)$, also different lactation numbers (CLN) did not affect claw conformation $(\mathrm{P}=0.587)$ and hindlimb conformation $(\mathrm{P}=0.815)$ groups (Table 3$)$.

A statistically significant difference $(\mathrm{P}=0.014)$ was found of BCS between Hin and OL cows (Table 4). The Hin cows showed a lower BCS (3.14) and OL cows had higher BCS (3.77) than other HiLC groups (Table 4). Claw conformation had no significant effect on BCS (Table 5).

Interaction between claw conformation, hindlimb conformation, and gait

The abnormal hindlimb conformation group was statistically significant $(\mathrm{P}<0.001)$ to have more abnormal claw conformation (68.2\%) than normal hindlimb cows $(33.3 \%)$. Abnormal Hin conformation was statistically higher than expected in cows with abnormal claw conformation $(\mathrm{P}<0.001)$. Only the Hin subgroup was have higher abnormalities than expected $(\mathrm{P}<0.001)$ (Table 6).

It was determined that Hin was statistically related $(\mathrm{P}<0.001)$ with the corkscrew claw, scissor claw, and big claw. Corkscrew claw incidence in all claws (LL, LM, RL, and RM) of Hin cows was a higher expected number than normal hindlimb conformed cows $(\mathrm{P}<0.001)$. Right medial claws of Hin cows had a higher expected number $(\mathrm{P}<0.001)$ of scissor claw than normal cows. Besides, both medial claws of Hin cows had a higher expected number $(\mathrm{P}<0.001)$ of big claw than normal hindlimb conformed cows (Table 7).

The cows, which had normal gait $(n=28)$, have a higher number of abnormal hindlimb

Table 2 - Distribution of claw conformations; each claw, number of the claws (n), and percentages (\%).

\begin{tabular}{lccccc}
\hline Claw conformation & \multicolumn{5}{c}{ Total } \\
\hline & LL & LM & RL & RM & \\
Normal claw & $101(60.8)$ & $114(68.7)$ & $100(60.2)$ & $114(68.7)$ & $429(64.6)$ \\
Scissor claw & $22(13.3)$ & $23(13.9)$ & $17(10.2)$ & $22(13.3)$ & $84(12.7)$ \\
Corkscrew claw & $35(21.1)$ & $16(9.6)$ & $39(23.5)$ & $18(10.8)$ & $108(16.3)$ \\
Big claw & $8(4.8)$ & $13(7.8)$ & $10(6.0)$ & $12(7.2)$ & $43(6.5)$
\end{tabular}

LL: Hind left leg lateral claw; LM: Hind left leg medial claw; RL: Hind right leg lateral claw; RM: Hind right leg medial claw. 
Table 3 - Influence of abnormal claw conformation, abnormal hindlimb conformation, categorized days in milk (CDIM), and categorized lactation number $(\mathrm{CLN})$ on body condition score $(\mathrm{BCS})(\mathrm{Mean} \pm \mathrm{SD})$.

\begin{tabular}{|c|c|c|c|c|}
\hline & ------Groups------------ & -----n----- & ---Mean \pm SD--- & --------p-value-------- \\
\hline \multirow{2}{*}{ Claw Conformation } & normal & 78 & $3.31 \pm 0.57$ & \multirow{2}{*}{0.461} \\
\hline & abnormal & 88 & $3.30 \pm 0.67$ & \\
\hline \multirow{2}{*}{ Hindlimb Conformation } & normal & 84 & $3.33 \pm 0.62$ & \multirow{2}{*}{0.226} \\
\hline & abnormal & 82 & $3.28 \pm 0.63$ & \\
\hline \multirow{3}{*}{ CDIM } & Early lactation & 13 & $2.88 \pm 0.61^{b}$ & \multirow{3}{*}{$<0.001$} \\
\hline & Peak lactation & 31 & $2.95 \pm 0.48^{b}$ & \\
\hline & Late lactation & 122 & $3.44 \pm 0.60^{\mathrm{a}}$ & \\
\hline \multirow{2}{*}{ CLN } & Young & 110 & $3.35 \pm 0.60$ & \multirow{2}{*}{0.296} \\
\hline & Old & 56 & $3.22 \pm 0.67$ & \\
\hline \multirow{4}{*}{ Interactions } & $\mathrm{CC}^{*} \mathrm{CDIM}$ & & & 0.886 \\
\hline & $\mathrm{HiLC}^{*}$ CDIM & & & 0.702 \\
\hline & $\mathrm{CC}^{*} \mathrm{CLN}$ & & & 0.587 \\
\hline & $\mathrm{HiLC}^{*} \mathrm{CLN}$ & & & 0.815 \\
\hline
\end{tabular}

CC: Claw conformation; HiLC: Hindlimb conformation; CDIM: Categorized days in milk; CLN: Categorized lactation number. a, b: Different superscripts are indicating the statistical difference.

conformation $(\mathrm{n}=19)$ than expected $(\mathrm{P}=0.032)$. These cows had also a higher number of abnormal claw conformation $(n=20)$ than expected; while the abnormal gait group had a smaller number of abnormal claw conformation than expected $(\mathrm{P}=0.032)$ (Table 8).

According to the fit statistics the model used was compatible $(\mathrm{P}=0.747)$. As a result of

Table 4 - Effect of hindlimb conformation on body condition score (Mean $\pm \mathrm{SD})$

\begin{tabular}{lcc}
\hline Hindlimb conformation & $\mathrm{n}$ & Body Condition Score (Mean \pm SD) \\
\hline Normal & 84 & $3.34 \pm 0.62^{\mathrm{ab}}$ \\
Hock in (Hin) & 51 & $3.14 \pm 0.62^{\mathrm{b}}$ \\
One side Hock in (OHin) & 8 & $3.38 \pm 0.69^{\mathrm{ab}}$ \\
Bow Legged (BL) & 8 & $3.19 \pm 0.53^{\mathrm{ab}}$ \\
Open Legged (OL) & 15 & $3.77 \pm 0.49^{\mathrm{a}}$ \\
P-value & & 0.014 \\
\hline
\end{tabular}

a, b. Different superscripts are indicating the statistical difference. univariate logistic regression analysis, an increase in CLN (to be old) and having an abnormal hindlimb conformation resulted in an increased risk of abnormal claw conformation by 2.29 times $(\mathrm{P}=0.036)$ and 4.98 times $(\mathrm{P}<0.001)$, respectively (Table 9 ).

\section{DISCUSSION AND CONCLUSION}

Front limbs and claws were not evaluated in this study since most claw disorders in dairy cows appear on the hind claws (SOLANO et al., 2016). BCS was evaluated from the backside of the cow (EDMONSON et al., 1989). Moreover, the evaluation of BCS, hindlimb, and claws during the feeding time might be made from the rear side and is thought that the method used in the study may be more effective for time management.

Reduced lameness in dairy cows contributed to animal welfare and farm economics (SOLANO et al., 2015; AKIN \& AKIN, 2018). It has been achieved by regular claw trimming and treatment strategies on claw diseases (LEACH et al., 2010; BICALHO \& OIKONOMOU, 2013; MAHENDRAN et al., 2017). However, improving on legs and claw conformation of dairy cattle by breeding strategies on the farm 
Table 5 - Effect of different claw conformation on body condition score [mean \pm SD].

\begin{tabular}{|c|c|c|c|c|c|c|c|c|c|c|}
\hline & & \multicolumn{2}{|c|}{---------Normal-------- } & \multicolumn{6}{|c|}{ 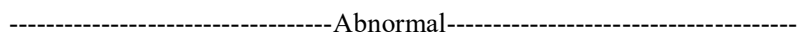 } & \multirow[b]{2}{*}{ p-value } \\
\hline & Claw & $\mathrm{NC}$ & $\mathrm{n}$ & $\mathrm{CoC}$ & $\mathrm{n}$ & $\mathrm{SC}$ & $\mathrm{n}$ & $\mathrm{BC}$ & $\mathrm{n}$ & \\
\hline \multirow{4}{*}{ BCS } & LL & $3.35 \pm 0.06$ & 101 & $3.21 \pm 0.12$ & 35 & $3.34 \pm 0.16$ & 22 & $3.35 \pm 0.25$ & 8 & 0.164 \\
\hline & LM & $3.36 \pm 0.06$ & 114 & $3.16 \pm 0.18$ & 16 & $3.28 \pm 0.14$ & 23 & $3.23 \pm 0.16$ & 13 & 0.113 \\
\hline & RL & $3.33 \pm 0.06$ & 100 & $3.32 \pm 0.11$ & 39 & $3.35 \pm 0.18$ & 17 & $3.15 \pm 0.21$ & 10 & 0.363 \\
\hline & RM & $3.36 \pm 0.06$ & 114 & $3.22 \pm 0.14$ & 18 & $3.23 \pm 0.15$ & 22 & $3.21 \pm 0.20$ & 12 & 0.200 \\
\hline
\end{tabular}

BCS: Body condition score; LL: Hind left leg lateral claw; LM: Hind left leg medial claw; RL: Hind right leg lateral claw; RM: Hind right leg medial claw; NC: Normal claw; CoC: Corkscrew claw; SC: Scissor claw; BC: Big claw.

level may contribute to reducing lameness prevalence in the next generations (CHAPINAL et al., 2013; ØDEGARD et al., 2014). Towards revealing this contribution, investigating the relationship between the leg and the claw of the cow enhances the current knowledge. This article provided information about this relationship through a commercial family dairy farm. Since this study used only one farm, the number of cows and claws in some of the subdivision groups were rather small and some claw shape abnormalities (such as asymmetric claws, concave wall, etc.) were not observed. However, the farm used in this study is one of the earliest established dairy farms in the Aydin region. By the declaration of the owner, after the establishment of the farm (since 1955), they did not use outside sources heifer and/or cow. This means that the mother line of the cows used in this study did not change since 1955. The effect of the unchanged mother line on limb and claw conformations has not been investigated in the present study. Nevertheless, this situation had a positive contribution to the study's aim and in the reliability of the results; and might be investigated in future studies.

Standardized and described 27 claw disorders have been reported (RESZLER, 2006; EGGER-DANNER, 2015). Also, the definition of normal (RAVEN, 1985) and abnormal (PIJL, 2003; RESZLER, 2006) conformation of the claw has been well described. As an abnormal claw conformation $\mathrm{CoC}, \mathrm{SC}$, and $\mathrm{BC}$ were recorded and evaluated in the present study, the other described abnormal conformations (PIJL, 2003; NGUHIU-MWANGI et al., 2012; EGGER-DANNER et al., 2015) were not encountered. Claw conformation was related

Table 6 - Relationship between the claw conformation and hindlimb conformation groups, the number of cows (n) and percentages (\%).

\begin{tabular}{|c|c|c|c|c|}
\hline & & -------------------Claw Co & 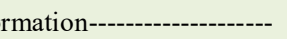 & \\
\hline & & ------abnormal, n (\%)------ & -----normal, n (\%)----- & --------p-value------- \\
\hline \multirow{2}{*}{ Main groups of HiLC } & Normal & $28(33.3)$ & $56(66.7)$ & \multirow{2}{*}{$<0.001$} \\
\hline & Abnormal & $60(68.2)$ & $22(28.2)$ & \\
\hline \multirow{4}{*}{ Subgroups of abnormal HiLC } & Hin $^{*}$ & $44(86.3)$ & $7(13.7)$ & \multirow{4}{*}{$<0.001$} \\
\hline & OHin & $5(62.5)$ & $3(37.5)$ & \\
\hline & $\mathrm{BL}$ & $4(50.0)$ & $4(50.0)$ & \\
\hline & $\mathrm{OL}$ & $7(46.7)$ & $8(53.3)$ & \\
\hline
\end{tabular}

\footnotetext{
*: Abnormal claw conformation existence was higher than expected on Hin cows than other abnormal hindlimb conformation subgroups. HiLC: Hindlimb conformation; Hin: Hock in; OHin: One side hock in; BL: Bow-legged and OL: Open legs.
}

Ciência Rural, v.52, n.4, 2022. 
Table 7 - The comparison of Hin and normal cows by their claw conformation of their every claw, the number of claws (n), and percentages $(\%)$.

\begin{tabular}{|c|c|c|c|c|c|c|c|}
\hline & & & --------Normal-------- & ------------------- & -Abnormal--- & -------------------- & \\
\hline Claw & ---HiLC--- & --Total, n (\%)-- & -----NC, n (\%)----- & $--\mathrm{CoC}, \mathrm{n}(\%)--$ & -SC, n (\%)- & --BC, n (\%)--- & ----p-value---- \\
\hline \multirow{2}{*}{ LL } & Normal & $84(62.2)$ & $65(78.3)$ & $10(33.3)$ & $7(46.7)$ & $2(28.6)$ & \multirow{2}{*}{$<0.001$} \\
\hline & Hin & $51(37.8)$ & $18(21.7)$ & $20(66.7)^{*}$ & $8(53.3)$ & $5(71.4)$ & \\
\hline \multirow{2}{*}{ LM } & Normal & $84(62.2)$ & $73(78.5)$ & $3(23.1)$ & $6(33.3)$ & $2(18.2)$ & \multirow{2}{*}{$<0.001$} \\
\hline & Hin & $51(37.8)$ & $20(21.5)$ & $10(76.9)^{*}$ & $12(66.7)$ & $9(81.8)^{*}$ & \\
\hline \multirow{2}{*}{ RL } & Normal & $84(62.2)$ & $65(82.3)$ & $10(31.3)$ & $7(46.7)$ & $2(22.2)$ & \multirow{2}{*}{$<0.001$} \\
\hline & Hin & $51(37.8)$ & $14(17.7)$ & $22(68.8)^{*}$ & $8(53.3)$ & $7(77.8)$ & \\
\hline \multirow{2}{*}{$\mathrm{RM}$} & Normal & $84(62.2)$ & $73(79.3)$ & $3(21.4)$ & $6(31.6)$ & $2(20.0)$ & \multirow{2}{*}{$<0.001$} \\
\hline & Hin & $51(37.8)$ & $19(20.7)$ & $11(78.6)^{*}$ & $13(68.4)^{*}$ & $8(80.0)^{*}$ & \\
\hline
\end{tabular}

P values characterize the values obtained from the Chi-square test. ${ }^{*}$ refers to the difference between statistically expected and observed percentages of claw conformation $(\mathrm{P}<0.001)$. HiLC: Hindlimb conformation; LL: Hind left leg lateral claw; LM: Hind left leg medial claw; RL: Hind right leg lateral claw; RM: Hind right leg medial claw; NC: Normal claw; CoC: Corkscrew claw; SC: Scissor claw; BC: Big claw.

to lameness (GITAU et al., 1997) and lameness in dairy cows linked positively with claw overgrowth (CRAMER et al., 2009; SOLANO et al., 2015). Uneven paired digits in length may lead to differences in hooves such as disbalance, chronic overload, and deformation (KELLER et al., 2009; MUGGLI et al., 2011; PARES-CASANOVA et al., 2020). Sickled rear legs, old age, and abnormal hooves were previously linked with locomotion problems (OSSENT et al., 1987; BOELLING et al., 1998). In addition to these findings, PARES-CASANOVA et al. (2020) have proposed to investigate asymmetry for kinematic analysis on old cow digits. In the present study, cows with abnormal hind limb conformation and old cows were more prone to have abnormal claws $(\mathrm{P}<0.001)$.
Also, having abnormal claw and abnormal hindlimb conformation were related to gait abnormality $(\mathrm{P}=0.032$; Table 8). Regarding the results of our study and the suggestion of PARES-CASANOVA et al. (2020), the investigation of the relation between the claw conformation, hindlimb conformation, and digit asymmetry for locomotion score would also be very interesting.

The transition period and age are important factors in asymmetric claw development (OSSENT et al., 1987). However, high milk yields and poor body conditions were associated with foot and leg conformation, and low body condition seems to be related to the non-infectious disorders of the claw (GREEN et al., 2014). The thickness of the digital

Table 8 - The relationship between gait and claw conformation and hindlimb conformation, the number of cows (n) and percentages (\%).

\begin{tabular}{|c|c|c|c|c|c|c|c|}
\hline \multirow[b]{2}{*}{ Gait } & \multicolumn{3}{|c|}{----------Hindlimb conformation----------- } & \multicolumn{3}{|c|}{------------Claw conformation-------------- } & \multirow[b]{2}{*}{-------Total------- } \\
\hline & --abnormal-- & ----normal---- & --p-value-- & --abnormal-- & ---normal--- & --p-value-- & \\
\hline Abnormal & $63(45.7)$ & $75(54.3)$ & \multirow{2}{*}{0.032} & $68(49.3)$ & $70(50.7)$ & \multirow{2}{*}{0.032} & $138(83.1)$ \\
\hline Normal & $19(67.9)$ & $9(32.1)$ & & $20(71.4)$ & $8(28.6)$ & & $28(16.9)$ \\
\hline Total & $82(49.4)$ & $84(50.6)$ & & $88(53.0)$ & $78(47.0)$ & & $166(100)$ \\
\hline
\end{tabular}


Table 9 - Odds ratios and 95\% confidence intervals for claw conformation.

\begin{tabular}{|c|c|c|c|c|c|c|}
\hline \multirow[t]{2}{*}{ Risk Factors } & \multicolumn{2}{|c|}{-------------------Lateral--------------- } & \multicolumn{2}{|c|}{ '------------'Medial--------------- } & \multicolumn{2}{|c|}{--------------General------------- } \\
\hline & OR $(95 \% \mathrm{CI})$ & p-value & OR $(95 \% \mathrm{CI})$ & p-value & OR $(95 \% \mathrm{CI})$ & p-value \\
\hline CLN (young/old) & $2.98(1.75-5.09)$ & $<0.001$ & $3.67(2.07-6.48)$ & $<0.001$ & $2.29(1.05-4.97)$ & 0.036 \\
\hline HiLC (normal/abnormal) & $4.18(2.56-6.84)$ & $<0.001$ & $6.20(3.52-10.92)$ & $<0.001$ & $4.98(2.52-9.84)$ & $<0.001$ \\
\hline Gait (normal/abnormal) & $1.14(0.58-2.25)$ & 0.695 & $0.94(0.47-1.89)$ & 0.857 & $0.71(0.25-1.96)$ & 0.509 \\
\hline
\end{tabular}

OR: Odds ratio, CI: Confidence interval. CLN: Categorized lactation number; HiLC: Hindlimb conformation.

cushion (important structure for the inner claw tissue, hence important to lameness) is profoundly linked to body condition; also, for the optimum achievement to reducing lameness incidence, $\mathrm{BCS}$ has been described as 2.5 minimum/and above (BICALHO et al., 2009; NEWSOME et al., 2017). Based on the feeding practices for each farm, the BCS of dairy cows may be changed. In our study, the late lactation group has statistically higher $(\mathrm{P}<0.001)$ BCS than early and peak lactation groups. However, according to our results, there was no difference between the mean BCS of abnormal claw conformation exist and non-exist groups $(\mathrm{P}=0.461)$ and abnormal HiLC exist and non-exist groups $(\mathrm{P}=0.226)$. Limb conformations in dairy cows can be evaluated from the side and rearview (RAVEN, 1985; PIJL, 2003). Hin was the most encountered $(n=51)$ abnormality for rear evaluation of hindlimbs in this study, and Hin cows have significantly more abnormal claw conformation than other hindlimb conformation groups $(\mathrm{P}<0.001)$.

One of the major causes of lameness in cattle is claw problems (MURRAY et al., 1996; PHILIPS, 2002). Limb conformation traits have been correlated with claw disorders (VAN DER WAAIJ et al., 2004), but further research into the association between claw conformation and hindlimb conformation is needed. Accordingly, with the data used in this study, the effect of CLN, hindlimb conformation, and gait on claw conformation was tried to illustrate. Due to the pregnancy and growing udder, altered postures of the hindlimbs and weight distribution changes on claws were described (BERGSTEN, 2001). Old cows in this study have 2.29 times $(\mathrm{P}=0.036)$ more risk than young cows to have abnormal claw conformation. Also having abnormal hindlimb conformation in this study, 4.97 times $(\mathrm{P}<0.001)$ increases the risk of abnormal claw conformation. Thus, the results revealed that the hindlimb conformation of cows used in the study has strong relation of both medial and lateral claw conformation (especially for corkscrew claw), and also the age of cows has a negative effect on claw conformations. Because the claw is produced, trimmed, and be a worn part of the limbs (VERMUNT \& GREENOUGH, 1995) and the most cause of the lameness (SOLANO et al., 2016), the effects of CLN (young/old), HiLC (normal/abnormal), and gait (normal/abnormal) on claw conformation were evaluated and presented (Table 9) in this study. It is quite difficult to reveal which's conformation (the hindlimb or the claw) is the result of the other's abnormal conformation. However, dairy calves may be monitored until their first, second, or third lactations to reveal this argument. In future research, all claw shapes and hindlimb abnormalities can be investigated by achieving a large number of cows and considering the claw trimming effect.

According to the current knowledge and the results of this study, during semen selection for breeding, regarding the mother's limb and claw confirmation may be good for the future life of calves, next generations, and farm economics. Further studies, considering the present results, might be useful for breeding strategies of the herd.

\section{ACKNOWLEDGMENTS}

The authors would like to thanks Assoc. Prof. Dr. Aykut Gokturk Uner, Assist. Prof. Dr. Tugba Akin, the Cattle Breeders Association of Aydin Province, and the Arif Gurdal Dairy Farm. This study was funded by the Aydin Adnan Menderes University, Scientific Research Foundation (grant number: VTF-19022).

\section{BIOETHICS AND BIOSECURITY COMMITTEE APPROVAL}

According to clause (b) of Article 2 of the Regulation on the Working Procedures and Principles of the Animal Experiments Ethics Committee published in the Official Gazette of Turkey dated 15.02.2014 and numbered 28914, it has been stated that there is no need for ethical committee approval in "Nonexperimental Clinical Veterinary Medicine practices". Since the 
experiment in the present study was classified as "routine clinical applications for diagnosis and treatment" and there was no contact with the animal during the study period, there was no need to report to the ethics committee. Aydin Adnan Menderes University, Scientific Research Foundation has confirmed the study with the number: VTF-19022.

\section{DECLARATION OF CONFLICT OF INTEREST}

We have no conflict of interest to declare.

\section{AUTHORS' CONTRIBUTIONS}

All authors contributed equally to the conception and writing of the manuscript. All authors critically revised the manuscript and approved the final version.

\section{REFERENCES}

AKIN, I.; AKIN, T. Economic impact of digital dermatitis treatment on a dairy farm: an application of the break-even analysis. Ciencia Rural, v. 48, n. 8, p. e20170791, 2018. Available from: $<$ https://www.scielo.br/scielo.php?script $=$ sci arttext\&pid=S0103 84782018000800604 $>$. Accessed: Jan. 28, 2021. doi: 10.1590/0103-8478cr20170791.

BERGSTEN, C. Effects of conformation and management system on hoof and leg diseases and lameness in dairy cows. Veterinary Clinics of North America: Food Animal Practice, v. 17, n. 1, p.1-23, 2001. Available from: <https://pubmed.ncbi.nlm.nih. gov/11320689/>. Accessed: May. 2, 2021. doi: 10.1016/s07490720(15)30051-7. PMID: 11320689.

BICALHO, R. C. et al. Strategies to analyze milk losses caused by diseases with potential incidence throughout the lactation: A lameness example. Journal of Dairy Science, v.91, n.7, p. 2653-2661, 2008. Available from: https://pubmed.ncbi.nlm.nih. gov/18565924/>. Accessed: Jan. 28, 2021.doi: 10.3168/jds.20070744 .

BICALHO, R. C.; OIKONOMOU, G. Control and prevention of lameness associated with hoof lesions in dairy cows. Livestock Science, v. 156, n. p. 96-105, 2013. Available from: $<$ https://www. sciencedirect.com/science/article/pii/S1871141313002679?casa token=I p75 46mWwAAAAA:MNqWkGILex5K7X8MqurQp JDV5iaknNbEV51EG8ZYn3HZiXzfwpTa hCl6xfqOOcwrJyoLSniA>. Accessed: Jan. 28, 2021. doi: 10.1016/j. livsci.2013.06.007

BICALHO, R.C. et al. Lameness in dairy cattle: A debilitating disease or a disease of debilitated cattle? A cross-sectional study of lameness prevalence and thickness of the digital cushion. Journal of Dairy Science, v. 92, n. 7, p. 3175-3184, 2009. Available from: $<$ https://pubmed.ncbi.nlm.nih.gov/19757545/>. Accessed: Jan. 28, 2021. doi: 10.3168/jds.2008-1827.

BOELLING, D.; POLLOTT, G. E. Locomotion, lameness, hoof and leg traits in cattle II. Genetic relationships and breeding values. Livestock Production Science, v. 54, n. 3, p. 205 215, 1998. Available from: <https://www.sciencedirect.com/science/article/ abs/pii/S0301622697001735>. Accessed: Jan. 28, 2021. doi: 10.1016/S0301-6226(97)00173-5.
CHAPINAL, N. et al. Genetic parameters for hoof lesions and their relationship with feet and leg traits in Canadian Holstein cows. Journal of Dairy Science, v. 96, n. 4, p. 2596-2694, 2013. Available from: <https://pubmed.ncbi.nlm.nih.gov/23415531/>. Accessed: Jan. 28, 2021. doi: 10.3168/jds.2012-6071.

CRAMER, G. et al. Herd-level risk factors for seven different foot lesions in Ontario Holstein cattle housed in tie stalls or free stalls. Journal of Dairy Science, v. 92, n. 4, p. 1404-1411, 2009. Available from: <https://pubmed.ncbi.nlm.nih.gov/19307621/>. Accessed: Jan. 28, 2021. doi: 10.3168/jds.2008-1134.

EDMONSON, A. J. et al. A body condition scoring chart for Holstein dairy cows. Journal of Dairy Science, v.72, n. 1, p. 68 78, 1989. Available from: <https://www.journalofdairyscience. org/article/S0022-0302(89)79081-0/abstract>. Accessed: Jan. 28, 2021. doi: 10.3168/jds.S0022-0302(89)79081-0.

EGGER-DANNER， C. Züchterische verbesserung der klauengesundheit - internationale entwicklungen und aktueller stand in österreich. in: Seminar des ausschusses für genetik der zentralen arbeitsgemeinschaft österreichischer rinderzüchter (ZAR), Salzburg, Austria (2015), pp. 33-44. Available from: $<$ https://zar.at/Downloads/ZAR-Seminar.html>. Accessed: Jan. 28,2021 .

EGGER-DANNER, C. et al., 2015. ICAR claw health atlas. First edition. Available from: $<$ https://www.icar.org/ICAR_Claw_ Health_Atlas.pdf.>.Accessed: May. 8, 2021.

GITAU, T. et al. Assessment of bovine hoof conformation and its association with lameness, animal factors and management practices on small-scale dairy farms in Kiambu district, Kenya. Onderstepoort Journal of Veterinary Research, v. 64, n. 2, p.135-140, 1997. Available from: <https://pubmed.ncbi.nlm.nih. gov/9352562/>. Accessed: Jan. 28, 2021.

GREEN, L. E. et al. Temporal associations between low body condition, lameness and milk yield in a UK dairy herd. Preventive Veterinary Medicine, v. 113, n. 1, p: 63-71, 2014. Available from: $<$ https://pubmed.ncbi.nlm.nih.gov/24183787/>. Accessed: Jan. 28, 2021. doi: 10.1016/j.prevetmed.2013.10.009.

HERINGSTAD, B. et al. Invited review: Genetics and claw health: Opportunities to enhance claw health by genetic selection. Journal of Dairy Science, v. 101, n. 6, p. 4801-4821, 2018. Available from: <https://www.sciencedirect.com/science/article/ pii/S0022030218302078>. Accessed: Jan. 28, 2020. doi: 10.3168/ jds.2017-13531.

KELLER, A. et al. Even-toed but uneven in length: the digits of artiodactyls. Zoology, v. 112 , n. 4, p. 270-278, 2009. Available from: <https://pubmed.ncbi.nlm.nih.gov/19386479/>. Accessed: Jan. 28, 2021. doi: 10.1016/j.zool.2008.11.001.

LEACH, K. A. et al. Working towards a reduction in cattle lameness: 1. Understanding barriers to lameness control on dairy farms. Research in Veterinary Science, v. 89, n. 2, p. 311-317, 2010. Available from: <https://www.sciencedirect.com/science/ article/abs/pii/S0034528810000676>. Accessed: Jan. 28, 2021. doi: 10.1016/j.rvsc.2010.02.014.

LIM, P. Y. et al. Unravelling the temporal association between lameness and body condition score in dairy cattle using a multistate modelling approach. Preventive Veterinary Medicine, v. 118, n. 4, p. 370-377, 2015. Available from: <https://www.sciencedirect. 
com/science/article/abs/pii/S0167587714004425>. Accessed: Jan. 28, 2021.doi: 10.1016/j.prevetmed.2014.12.015.

MAHENDRAN, S. A. et al. Randomised controlled trial to evaluate the effect of foot trimming before and after first calving on subsequent lameness episodes and productivity in dairy heifers. The Veterinary Journal, v. 220, p. 105-110, 2017. Available from: <https://pubmed.ncbi.nlm.nih.gov/28190486/>. Accessed: Jan. 28, 2021. doi: 10.1016/j.tvj1.2017.01.011.

MUGGLI, E. et al. Length asymmetry of the bovine digits. The Veterinary Journal, v. 188, n, 3, p. 295-300, 2011. Available from: <https://pubmed.ncbi.nlm.nih.gov/21570662/>. Accessed: Jan. 28, 2021. doi: 10.1016/j.tvj1.2010.05.016.

MURRAY, R. et al. Epidemiology of lameness in dairy cattle: Description and analysis of foot lesions. Veterinary Record, $v$. 138, n. 24, p. 586-591, 1996. Available from: <https://pubmed. ncbi.nlm.nih.gov/8799985/>. Accessed: Jan. 28, 2021. doi: 10.1136/vr.138.24.586.

NEWSOME, R. F. et al. A prospective cohort study of digital cushion and corium thickness. Part 1: Associations with body condition, lesion incidence, and proximity to calving. Journal of Dairy Science, v. 100, n. 6, p. 4745-4758, 2017. Available from: $<$ https://pubmed.ncbi.nlm.nih.gov/28434744/>. Accessed: Jan. 28, 2021. doi: $10.3168 /$ jds.2016-12012.

NGUHIU-MWANGI, J. et al. Risk (predisposing) factors for non- infectious claw disorders in dairy cows under varying zero-grazing systems. 2012. In: A Bird's-Eye View of Veterinary Medicine, Dr. Carlos C. Perez-Marin (Ed.), ISBN: 978-95351-0031-7, InTech, Available from: <https://www.intechopen. com/books/a-bird-s-eye-view-of-veterinary-medicine/riskpredisposing-factors-for-non-infectious-claw-disorders-in-dairycows-under-varying-zero-grazing $>$. Accessed: May. 8, 2021.

ØDEGARD, C. et al. Genetic correlations between claw health and feet and leg conformation in Norwegian Red cows. Journal of Dairy Science, 97, n. 7, p. 4522-4529, 2014. Available from: $<$ https://pubmed.ncbi.nlm.nih.gov/24767887/>. Accessed: Jan. 28, 2021. doi: 10.3168/jds.2013-7837.

OSSENT, P. et al. Distribution of load between the lateral and medial hoof of the bovine hind limb. Journal of Veterinary Medicine Series A, v. 34, n. 1-10, p. 296-300, 1987. Available from: $\quad<$ https://onlinelibrary.wiley.com/doi/abs/10.1111/j.1439 0442.1987.tb00283.x>. Accessed: Jan. 28, 2021. doi: 10.1111/ j.1439-0442.1987.tb00283.x.

PARES-CASANOVA, P. M. et al. Asymmetries of forelimb digits of young cattle. Veterinary Sciences, v. 7, n. 3, p. 83, 2020. Available from: <https://pubmed.ncbi.nlm.nih.gov/32630632/>. Accessed: Jan. 28, 2021. doi: 10.3390/vetsci7030083.

PIJL, R. Klauenprobleme schneller lösen. Landwirtsshaftsverlag Gmbh, Münster-Hiltrup, Germany, 2003. 88p.

RANDALL, L. V. et al. Low body condition predisposes cattle to lameness: An 8-year study of one dairy herd. Journal of Dairy Science, v. 98, n. 6, p. 3766-3777, 2015. Available from: $\quad<$ https://www.sciencedirect.com/science/article/pii/ S002203021500209X>. Accessed: Jan. 28, 2021. doi: 10.3168/ jds.2014-8863.
RAVEN, T. E. et al. Cattle footcare and hoof trimming. Farming Press, Ipswich, Suffolk, UK. 1985. 126p.

RESZLER, G. Handbuch klauen: Grundlagen für die erhaltung einer stabilen klauengesundheit. AVA-Broschüre, Nutztierpraxis Rind, 1. ed. Agrar- und Veterinär-Akademie, Horstmar-Leer, 2006.

SADIQ, M. B. et al. Claw trimming as a lameness management practice and the association with welfare and production in dairy cows. Animals (Basel), v. 10(9), 1515. Available from: $<$ https://pubmed.ncbi.nlm.nih.gov/32867064/>. Accessed: May. 3, 2021. doi: 10.3390/ani10091515. PMID: 32867064; PMCID: PMC7552284.

SOLANO, L. et al. Prevalence of lameness and associated risk factors in Canadian Holstein Friesian cows housed in freestall barns. Journal of Dairy Science, v. 98, n. 10, p. 6978-6991, 2015. Available from: <https://pubmed.ncbi.nlm.nih.gov/26254526/>. Accessed: Jan. 28, 2021. doi: 10.3168/jds.2015-9652.

SOLANO, L. et al., Prevalence and distribution of foot lesions in dairy cattle in Alberta, Canada. Journal of Dairy Science, v. 99, n. 7, p. 6828-6841, 2016. Available from: $<$ https://www.sciencedirect. com/science/article/pii/S0022030216302946>. Accessed: May. 1, 2021. doi: 10.3168/jds.2016-10941.

SPRECHER, D. J. A lameness scoring system that uses posture and gait to predict dairy cattle reproductive performance. Theriogenology, v. 47, n. 6, p. 11791116, 1997. Available from: $<$ https://pubmed.ncbi.nlm.nih.gov/16728067/>. Accessed: Jan. 28, 2021. doi: 10.1016/s0093-691x(97)00098-8.

VAN DER LINDE, et al. Claw health index for Dutch dairy cattle based on claw trimming and conformation data. Journal of Dairy Science, v. 93, n. 10, p. 4883-4891, 2010. Available from: <https:// www.sciencedirect.com/science/article/pii/S0022030210005205>. Accessed: Jan. 28, 2021.doi: 10.3168/jds.2010-3183.

VAN DER WAAIJ, et al. Genetic parameters for claw disorders in Dutch dairy cattle and correlations with conformation traits. Journal of Dairy Science, v. 88, n. 10, p. 3672-3678, 2005. Available from: <https://www.sciencedirect.com/science/article/ pii/S0022030205730538>. Accessed: May. 1, 2021. doi: 10.3168/ jds.S0022-0302(05)73053-8.

VERMUNT, J. J.; GREENOUGH, P. R. Structural characteristics of the bovine claw: Horn growth and wear, horn hardness and claw conformation. British Veterinary Journal. v. 151, n. 2, p. 157-180, 1995. Available from: <https:/www.sciencedirect.com/ science/article/abs/pii/S0007193595800077>. Accessed: May. 1, 2021. doi:10.1016/s0007-1935(95)80007-7.

WARNICK, L. D. et al. The effect of lameness on milk production in dairy cows. Journal of Dairy Science, v. 84, n. 9, p. 1988-1897, 2001. Available from: <https://www.sciencedirect.com/science/ article/pii/S0022030201746425>. Accessed: Jan. 28, 2021. doi: 10.3168/jds.S0022-0302(01)74642-5.

ZWALD, et al. Genetic selection for health traits using producerrecorded data. I. Incidence rates, heritability estimates, and sire breeding values. Journal of Dairy Science, v. 87, n. 12, p. 4287 4294, 2004. Available from: <https:/www.sciencedirect.com/ science/article/pii/S0022030204735730>. Accessed: Jan. 28, 2021. doi: 10.3168/jds.S0022-0302(04)73573-0. 